\title{
$\beta$-Arrestin2 Inhibits Expression of Inflammatory Cytokines in BEAS-2B Lung Epithelial Cells Treated with Cigarette Smoke Condensate via Inhibition of Autophagy
}

\author{
Yanjun Wu Yunxiao Li Bo Wu Chunting Tan Xin He Bo Xu Ganggang Yu \\ Haoyan Wang
}

Department of Respiratory Medicine, Beijing Friendship Hospital, Capital Medical University, Beijing, China

\section{Key Words}

$\beta$-Arrestin2 • Cigarette smoke • Inflammation • Autophagy • Chronic obstructive pulmonary disease

\begin{abstract}
Background/Aims: $\beta$-arrestin2 has been shown to have a role in human inflammatory disease. However, the role of $\beta$-arrestin2 in cigarette smoke-induced inflammation in the lung remains unknown. The aims of this study were to investigate the effects of $\beta$-arrestin2 on cigarette smoke condensate (CSC)-induced expression of inflammatory cytokines in the BEAS-2B human bronchial epithelial cell line in vitro, and the mechanisms involved. Methods: The MTT assay determined cell viability of cultured BEAS-2B cells. Autophagy was assessed by western blot, adenoviral mRFP-GFP-LC3 transfection, and immunofluorescence. The effects of $\beta$-arrestin2 shRNA knockdown were studied by western blot and real-time reverse transcription-polymerase chain reaction (RT-PCR). Western blot evaluated the AMPK/mTOR signaling pathway. Levels of inflammatory cytokines, interleukin (IL)-6, IL-8, and MCP-1 were measured in cell culture supernatants by enzyme-linked immunosorbent assay (ELISA). Results: CSC suppressed expression of $\beta$-arrestin2 in BEAS-2B cells, activated the AMPK/ mTOR signaling pathway, increased cell autophagy and the expression of IL-6, IL-8, and MCP1 , pretreatment with the $\beta$-arrestin2 biased ligands, propranolol, and ICI118551 reversed these changes. Inhibition of autophagy reduced the expression of inflammatory cytokines following CSC. Conclusion: In the human bronchial epithelial cell line, BEAS-2B, $\beta$-arrestin2 reduced the expression of CSC-induced inflammatory cytokines by inhibiting autophagy, most likely via the AMPK/mTOR signaling pathway.




\section{Cellular Physiology Cell Physiol Biochem 2018;50:1270-1285 and Biochemistry Published online: 25 October 2018 \begin{tabular}{l|l} 
DOI: $10.1159 / 000494586$ & $\begin{array}{l}\text { (c) The Author(s). Published by S. Karger AG, Basel } \\
\text { www.karger.com/cpb }\end{array}$
\end{tabular} \\ Wu et al:: The Role of $\beta$-Arrestin2 in Inflammation of Beas-2B Cells Induced by CSC}

\section{Introduction}

Chronic obstructive pulmonary disease (COPD) is a common respiratory disease characterized by not entirely reversible airflow limitation and clinical symptoms including a chronic cough, dyspnea, and sputum production. COPD exerts a severe effect upon a patient's quality of life and brings heavy economic burden to the families of patients and society in general. Worldwide, COPD currently ranks as the third most common cause of death and the fifth most common cause of chronic disability $[1,2]$. However, the etiology and pathogenesis of COPD are still not completely understood, and at present, are generally considered to be closely related to exposure to cigarette smoke which is the most common risk factor for the occurrence and development of COPD [3, 4].

The mechanisms responsible for lung inflammation as a result of cigarette smoke are highly complex. Chromatographic analysis and mass spectrometry have shown that cigarette smoke contains more than 47, 000 chemical substances, although the main components are nicotine, carbon monoxide and coal tar [5]. Research has shown that cigarette smoke can directly cause bronchial epithelial cells to release a large number of inflammatory cytokines, including tumor necrosis factor-alpha (TNF- $\alpha$ ), IL-6, and IL-1 $\beta$. Inflammatory cytokines released by exposure to cigarette smoke can also induce inflammatory cells such as neutrophils, macrophages and lymphocytes to migrate to the airway epithelium and exacerbate the secretion of inflammatory cytokines, which represents a cascade of amplification of inflammation [6,7]. Therefore, the control of lung inflammation is of vital importance to the prevention and treatment of COPD.

Arrestin was first discovered by Benovic et al [8]. while purifying $\beta$-adrenoceptor kinase from the bovine brain. Thus far, four family members of arrestin have been identified. Arrestin 1 and arrestin 4 are restricted to the visual system and regulate the conduction of light signals. In contrast, arrestin 2 and arrestin 3 (also known as $\beta$-arrestin 1 and $\beta$-arrestin 2 ) are widely distributed throughout mammalian tissues [9]. Recent studies have shown that $\beta$-arrestin is not only involved in the desensitization, internalization, and circulation of $\beta 2$-adrenergic receptors, but also serves as a signaling pathway independent of G-protein, which has become known as the $\beta$-arrestin bias signaling pathway [9-15]. Propranolol, as a non-selective beta-blocker, blocks the $\beta$-adrenoceptor signaling pathway which is coupled to a G-protein ,but prefers to activate the $\beta$-arrestin dependent signaling pathway which is independent of $\mathrm{G}$ protein. This mechanism is similar to that seen with the non-selective betablocker/alpha-1 blocker, carvedilol, and the selective $\beta 2$ adrenergic receptor antagonist, ICI118551 [10, 16].

Autophagy is a process that involves the phagocytosis of impaired or degenerating proteins and organelles within cells, encapsulates these components into vesicles that fuse with lysosomes that are degraded [17]. Autophagy plays an important role in cell homeostasis $[18,19]$, cancer [20], oxidative stress [21, 22], and inflammatory diseases [23, 24]. There is published evidence to support that autophagy plays an important role in the lung inflammation in COPD $[25,26]$. For example, in a previous study published by our group, we found that the levels of pulmonary autophagy in a COPD mouse model were increased, and that the levels of inflammatory cytokines in bronchoalveolar lavage (BAL) fluid were also increased [27]. In another study, Li and co-workers found that silymarin reduced airway inflammation induced by cigarette smoke by inhibiting autophagy and the ERK/p38 MAPK pathway [28].

We have also previously shown that 14, 15-epoxyeicosatrienoic acid treatment reduces the CSC-induced inflammatory response in bronchial epithelial cells in vitro by inhibiting autophagy through the PI3K/AKT/mTOR signaling pathway [29]. LC3 is a characteristic microtubule-associated protein light chain; when autophagy is activated, LC3-I is converted to LC3-II, and as a consequence, the LC3-II level would be expected to rise. P62/SQSTM1 (P62) is a multifunctional protein that contains a variety of protein domains and plays an important role in many diseases [30]. During the formation of autophagosomes, P62 acts as a bridge between LC3 and polyubiquitinated proteins, transporting damaged organelles or 


\section{Cellular Physiology Cell Physiol Biochem 2018;50:1270-1285 \begin{tabular}{l|l|l} 
DOI: 10.1159/000494586 & Ond 2018 The Author(s). Published by S. Karger AG, Basel \\
www.karger.com/cpb
\end{tabular} \\ Wu et al.: The Role of $\beta$-Arrestin2 in Inflammation of Beas-2B Cells Induced by CSC}

invading bacteria into the autophagosomes via the ubiquitin signal pathway, with both the content of the autophagosome and P62 being subsequently degraded. Therefore, P62 levels are negatively correlated with the degree of autophagy, and levels of LC3-II and P62 can be used as markers of autophagy [31].

Previously published studies have shown that $\beta$-arrestin 2 is involved in the occurrence and development of a range of pathological conditions, including diseases of the nervous system [32, 33], dilated cardiomyopathy [34], colitis [35], tumors [36] and inflammatory diseases $[37,38]$. Carr et al. demonstrated that the $\beta$-arrestin bias signaling pathway could promote the contraction of myocardial cells [16]. Ryter et al. reported that $\beta$-arrestin2 improved the function of cardiac myocytes in patients with dilated cardiomyopathy [34]. Sun et al. showed that the expression of $\beta$-arrestin 2 was reduced in liver cancer and that the overexpression of $\beta$-arrestin 2 inhibited the migration of liver cancer cells in vitro [36]. Liu et al. have shown that $\beta$-arrestin promoted podocyte injury in diabetic nephropathy by inhibiting autophagy [39]. Jiang et al. reported that in inflammatory diseases, $\beta$-arrestin2 reduced lipopolysaccharide (LPS)-induced liver cell injury by inhibiting the TLR4/NF- $\mathrm{B}$ pathway [40]. A study by Gaffal et al. showed that $\beta$-arrestin2 reduced inflammation in atopic dermatitis by reducing the recruitment of immune cells [37]. Fan et al. showed that $\beta$-arrestin2 reduced the cecal ligation and puncture (CLP)-induced inflammatory response in experimental sepsis [41]. Therefore, the role of $\beta$-arrestin 2 in inflammatory processes in cells, animal models, and in human tissues is supported by recently published studies.

However, the role of $\beta$-arrestin2 regulates in inflammation of the lung induced by cigarette smoke remains unclear, but is an important area to study, given the prevalence and clinical morbidity associated with COPD, which results from chronic lung damage due to inflammation in people who smoke. Based on the findings of our previous study, and supported by the recent literature, the aims of the present study were to investigate the effects of $\beta$-arrestin2 on CSC-induced expression of inflammatory cytokines in the BEAS-2B human bronchial epithelial cell line in vitro and the mechanisms involved. The methods used included cell viability and autophagy assays, virus transfection, laser confocal immunofluorescence microscopy, western blot and enzyme-linked immunosorbent assay (ELISA) to measure inflammatory cytokines, and real-time reverse transcription polymerase chain reaction (RT-PCR).

\section{Materials and Methods}

\section{Chemicals and reagents}

Primary antibodies to P62 and mTOR were purchased from Abcam (Cambridge, MA, USA). Antibodies to $\beta$-arrestin2, AMPK, phospho-AMPK (Thr172) and phospho-mTOR (Ser2448) were purchased from Cell Signaling Technology (Beverly, MA, USA). Antibodies to GAPDH and LC3 were obtained from ProteinTech Group (Chicago, IL, USA). Rapamycin, 3-methyladenine (3-MA), propranolol, and ICI118551 were purchased from Sigma-Aldrich (St. Louis, MO, USA). ELISA kits for Human IL-6, IL-8, and MCP-1 were obtained from Biolegend (San Diego, CA, USA) and mRFP-GFP-LC3 adenoviral vectors were obtained from HanBio Technology Co. Ltd (Shanghai, China). Lentiviral vectors carrying shRNAs specific for human $\beta$-arrestin2 were purchased from Cyagen Biosciences (Guangzhou, China) and UltraSYBR Mixture (with ROX) was purchased from CWBio. Co. Ltd (Beijing, China).

\section{Preparation of CSC}

CSC was prepared as described previously [29], but with some modifications. Briefly, a plastic bottle was connected to a hose and sealed tightly. The other end of the hose was connected to a cigarette Daqianmen, which is a popular type of cigarette in China containing $11 \mathrm{mg}$ tar and $0.8 \mathrm{mg}$ nicotine. The cigarette was ignited and the plastic bottle was placed in liquid nitrogen in order for cooling to take place. Using this method, cigarette smoke was solidified on the walls of the plastic container and could be scraped off with a spoon, weighed, dissolved in dimethylsulfoxide (DMSO) (Sigma-Aldrich, St. Louis, MO, USA) at a concentration of $600 \mathrm{mg} / \mathrm{ml}$ and then stored at $-80^{\circ} \mathrm{C}$. 


\section{Cellular Physiology Cell Physiol Biochem 2018;50:1270-1285 \begin{tabular}{ll|l} 
DOl: 10.1159/000494586 & O 2018 The Author(s). Published by S. Karger AG, Basel \\
www.karger.com/cpb
\end{tabular}}

Wu et al.: The Role of $\beta$-Arrestin2 in Inflammation of Beas-2B Cells Induced by CSC

\section{Cell culture and treatment}

BEAS-2B human lung epithelial cells were purchased from the American Type Culture Collection (Rockville, MD, USA) and seeded in M199 medium (Gibco) containing 10\% fetal bovine serum (HyClone) and cultured in a cell incubator at $37^{\circ} \mathrm{C}$ with $5 \% \mathrm{CO}_{2}$ and $95 \%$ air. The cells were spindle-shaped and grew in an adherent manner. Culture media was changed every 2-3 days. During the logarithmic growth phase, cells were treated with propranolol $(10 \mu \mathrm{M})$, ICI118551 $(1 \mu \mathrm{M})$, rapamycin $(50 \mathrm{nM})$, and 3-MA $(200 \mu \mathrm{M})$ for $1 \mathrm{~h}$ before intervention with CSC $(300 \mathrm{mg} / \mathrm{L})$. The control group and other groups contained a 1:1000 dilution of DMSO.

\section{MTT assay}

BEAS-2B cells $\left(10^{4}\right)$ were transferred from a single cell suspension into each well on a 96-well plate, with each well containing $200 \mu \mathrm{l}$ of culture medium. Cells were then treated with different concentrations of CSC at different time-points. Then, $20 \mu \mathrm{l}$ of MTT solution $(5 \mathrm{mg} / \mathrm{ml})$ was added into each well and incubated for another $4 \mathrm{~h}$. The liquid from each well was then removed and replaced with $150 \mu \mathrm{l}$ of DMSO. The plates were then oscillated for $10 \mathrm{~min}$. A wavelength of $570 \mathrm{~nm}$ was selected to measure the absorption of different groups on the microplate reader. The results were shown as a percentage of the control. All experiments were performed in triplicate.

\section{Transfection assay and adenoviral tandem fluorescent-tagged LC3 (mRFP-GFP-LC3) analysis}

The procedure used to transfect and evaluate adenoviral mRFP-GFP-LC3 has been described previously [29]. Briefly, the day before transfection, good quality BEAS-2B cells were seeded into 24-well plates and cultured overnight. The next day, and at a cell density of between $50-70 \%$, viral infection was performed. The adenoviral mRFP-GFP-LC3 was removed from the $-80^{\circ} \mathrm{C}$ freezer in advance and thawed on ice. Transfection steps were performed in strict accordance with the manufacturer's instructions. BEAS-2B cells were transfected with adenoviral mRFP-GFP-LC3 at a multiplicity of infection (MOI) value of 50. The medium was refreshed $6 \mathrm{~h}$ later and the cells were cultured for a further $24 \mathrm{~h}$. Transfected BEAS-2B cells were treated with propranolol $(10 \mu \mathrm{M})$, ICI118551 $(1 \mu \mathrm{M})$, rapamycin $(50 \mathrm{nM})$, and 3-MA $(200 \mu \mathrm{M})$ for $1 \mathrm{~h}$ prior to CSC intervention (300 mg/L). Cells were then left to incubate for an additional $24 \mathrm{~h}$. Cells were then fixed with $4 \%$ paraformaldehyde and viewed under a laser scanning confocal microscope (Olympus, Tokyo, Japan). The yellow spots which appeared after merge indicated autophagosomes, the red spots indicated autolysosomes.The intensity of autophagic change could be determined by counting the different colored fluorescent dots on confocal microscopy. We use an artificial counting method, and at least 50 cells were counted in each experiment.

\section{Lentiviral $\beta$-arrestin2 shRNA vector construction and transfection}

Lentiviral vectors were designed to carry shRNAs specific to three target sequences within human $\beta$-arrestin2, as follows:

5'-GCTAAATCACTAGAAGAGAAA-3';

5'-GATACCAACTATGCCACAGAT-3';

5'-CTTCCGCAAAGACCTGTTCAT-3'

and scramble shRNA5'-CCTAAGGTTAAGTCGCCCTCG-3'.

Cells were transfected with $\beta$-arrestin2 shRNA, or negative control shRNA, in accordance with the manufacturer's instructions. The lentivirus was then used to transfect BEAS-2B cells at 5 MOI. After $48 \mathrm{~h}$, transfection efficiency was confirmed by fluorescence microscopy. The knockdown efficiency of shRNA was then verified by real-time reverse transcription-polymerase chain reaction (RT-PCR) and western blot.

\section{Enzyme-linked immunosorbent assay (ELISA)}

Supernatants from different groups of cells were collected and used to determine the concentration of inflammatory cytokines. IL-6, IL-8, and MCP-1 were assayed by a human IL-6, IL-8, and MCP-1 ELISA MAX Deluxe product (Biolegend, San Diego, CA, USA) in accordance with the manufacturer's instructions. Each experiment was performed in triplicate. 


\section{Cellular Physiology Cell Physiol Biochem 2018;50:1270-1285

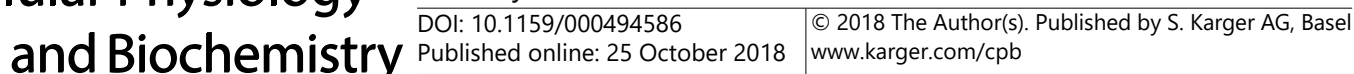

\section{Western blot}

BEAS-2B cells were harvested from 6-well plates, and total protein was extracted with RIPA buffer (Beyotime, Shanghai, China) containing protease inhibitors and phosphoric acid protease inhibitors. The BCA assay kit (Thermo Fisher Scientific) was then used to determine the concentrations of each protein sample. For each sample, $20 \mu \mathrm{g}$ of protein was loaded per well and separated by $8 \%$ or $12 \%$ sodium dodecyl sulfate-polyacrylamide gel electrophoresis (SDS-PAGE). Separated proteins were then transferred to nitrocellulose membranes (Applygen Technology, Beijing, China) at $300 \mathrm{~mA}$ for $60 \mathrm{~min}$. The membranes were probed with primary antibodies to $\beta$-arrestin2 (1:1000) (Cat. No. 3857), AMPK (1:1000) (Cat. No.5832), p-AMPK (1:1000) (Cat. No.2535), p-mTOR (1:1000) (Cat. No.5536), mTOR (1:1000) (Cat. No. ab32028), LC3 (1:1000) (Cat. No. 14600-1-AP), P62 (1:1000) (Cat. No.ab56416), and GAPDH (1:10000) (Cat. No.60004-1-lg) overnight at $4^{\circ} \mathrm{C}$ with gentle shaking. After washing, the membrane was incubated with corresponding horseradish peroxidase (HRP)-conjugated secondary antibodies (1:5000) (Zhongshan Jinqiao Biotechnology Co, Beijing, China) for $1 \mathrm{~h}$. Immunoreactivity was visualized with a chemiluminescence substrate (Thermo Fisher Scientific) using a western blot imaging system (Bio-Rad, Hercules, CA,USA).

\section{Real-time polymerase chain reaction (RT-PCR)}

Total RNA was extracted from cell samples using an ultra-pure RNA extraction kit (CWBio. Co. Ltd) (Cat. No. CW0581). Reverse transcription was then performed using the HiFi-MMLV cDNA First Strand Synthesis Kit (CWBio. Co., Ltd) (Cat. No. CW0744), according to the manufacturer's instructions. SYBR Green I real-time RT-PCR was then used to detect $\beta$-arrestin 2 mRNA transcription levels.

The following primers were obtained from Cyagen Biosciences (Guangzhou, China):

5'-GTAGATGGCGTGGTGCTTGTG-3'(F);

5'-AGGTGGCGATGAACAGGTCTT-3'(R);

GAPDH,5'-CTGGGCTACACTGAGCACC-3'(F) and

5'-AAGTGGTCGTTGAGGGCAATG-3' (R).

Cycling conditions were as follows: $95^{\circ} \mathrm{C}$ for $10 \mathrm{~min}$, followed by 45 cycles of $95^{\circ} \mathrm{C}$ for $15 \mathrm{~s}$ and $60^{\circ} \mathrm{C}$ for $60 \mathrm{~s}$. Reactions were performed using a Line Gene 9600 Plus fluorescence quantitative PCR system, and analyzed data using the $2^{-\triangle \Delta \mathrm{CT}}$ method.

\section{Immunofluorescence}

BEAS-2B cells were transfected with $\beta$-arrestin 2 shRNA or scramble shRNA, and treated with or without CSC (300 mg/L) for $24 \mathrm{~h}$. Cell slides were washed three times with PBS and fixed with $4 \%$ paraformaldehyde for 15 min and then permeabilized with $0.2 \%$ Triton X-100 for $10 \mathrm{~min}$ at room temperature. Normal goat serum was added to the slides and left to incubate at room temperature for $30 \mathrm{~min}$ to block non-specific antibody binding sites. The primary antibody to P62 (1:100) (Cat. No. ab56416) was then added to each slide and the slides placed in a humid box overnight at $4^{\circ} \mathrm{C}$.

The next morning, the slides were washed three times with PBST and incubated with Alexa Fluor 647 goat anti-mouse IgG antibody (1:500) (Abcam, Cambridge, MA, USA) (Cat.No.ab150119) in a humid box at $37^{\circ} \mathrm{C}$ for $1 \mathrm{~h}$,and then ,cells were stained with the blue DNA fluorescent stain 4,6-diamidino-2-phenylindole (DAPI) for $5 \mathrm{~min}$, sealed with a mounting medium containing anti-fluorescence quencher, and then analyzed under a fluorescence microscope (Olympus, Tokyo, Japan).

\section{Statistical analysis}

Data were analyzed using the GraphPad Prism6 (GraphPad Software, Inc., San Diego, CA, USA). Data were generated from at least three independent experiments and expressed as the mean \pm standard deviation (SD). Data were analyzed using the t-test and one-way analysis of variance (ANOVA). P-values $<0.05$ were considered to be statistically significant. 


\section{Cellular Physiology Cell Physiol Biochem 2018;50:1270-1285 \begin{tabular}{l|l|l|l} 
DOl: 10.1159/000494586 & O 2018 The Author(s). Published by S. Karger AG, Basel \\
wwww.karger.com/cpb
\end{tabular}

\section{Results}

Toxicity of CSC and its effect on the secretion of inflammatory cytokines in Beas-2B cells MTT assays confirmed the cytotoxicity of CSC on BEAS-2B cell lines. As shown in Fig. 1A, cell viability was reduced in a dose-dependent and time-dependent manner after exposure to different concentrations of CSC during different time points. Cell viability was approximately $70 \%$ when exposed to a level of $300 \mathrm{mg} / \mathrm{L} \mathrm{CSC}$ for $24 \mathrm{~h}$. Therefore, $300 \mathrm{mg} / \mathrm{L}$ of CSC was used for $24 \mathrm{~h}$ in subsequent experiments. Dimethylsulfoxide (DMSO) was added at a dilution of 1:1000 to the control group at different time points, and the cell viability of BEAS-2B cells was unaffected. Thus,In future experiments, the concentration of DMSO in all groups used was 1:1000.

An enzyme-linked immunosorbent assay (ELISA) was used to investigate whether CSC exposure affected the expression of inflammatory cytokines in BEAS-2B cells. On exposure to $300 \mathrm{mg} / \mathrm{L} \mathrm{CSC}$ for $24 \mathrm{~h}$, the secretion of the inflammatory cytokines IL-6 (Fig. 1B), IL-8 (Fig. 1C) and MCP-1 (Fig. 1D) in the cell supernatants increased in a time-dependent manner, indicating that CSC exposure increased the production of inflammatory cytokines in BEAS2B cells.

\section{Effect of CSC on the expression of $\beta$-arrestin2 and autophagy in BEAS-2B cells}

To investigate whether $\beta$-arrestin2 and autophagy were involved in regulating the cigarette smoke-induced inflammatory response, the effects of CSC on the expression of $\beta$-arrestin 2 and autophagy in lung epithelial cells was investigated using western blot. BEAS2B cells were cultured in $60 \mathrm{~mm}$ diameter dishes and exposed to $300 \mathrm{mg} / \mathrm{L}$ of CSC during their logarithmic growth phase. Cells were harvested at defined time intervals, and western blot showed that the expression of $\beta$-arrestin 2 decreased significantly after intervention with $300 \mathrm{mg} / \mathrm{L}$ of CSC for $6 \mathrm{~h}$ (Fig. 2B). Exposure to CSC also increased autophagy level in BEAS-2B cells. The expression of P62 levels was significantly reduced $24 \mathrm{~h}$ after CSC intervention (Fig. 2C). The expression of LC3-II increased significantly after CSC intervention for $24 \mathrm{~h}$ (Fig. 2D).

Fig. 1. Toxicity of CSC and its effect on the secretion of inflammatory cytokines in BEAS-2B cells. (A) $\mathrm{CSC}$ reduced the viability of BEAS2B cells in a dose-dependent and time-dependent manner. Cell viability was approximately $70 \%$ when exposed to a concentration of $300 \mathrm{mg} / \mathrm{L}$ CSC for $24 \mathrm{~h}$. Cell viability was unaffected when exposed to a 1:1000 concentration of dimethylsulfoxide (DMSO) at different time points. (B, C, and D) Levels of the inflammatory cytokines, IL-6, IL-8, and MCP-1, in the cell supernatant increased after exposure to $300 \mathrm{mg} / \mathrm{L} \mathrm{CSC}$ for the indicated time intervals in BEAS-2B cells. There was a statistically significant increase after exposure for $2 \mathrm{~h}$. Data represent the mean \pm SD of three independent experiments. ${ }^{*} \mathrm{P}<0.05$ vs. the control group.

\section{B}

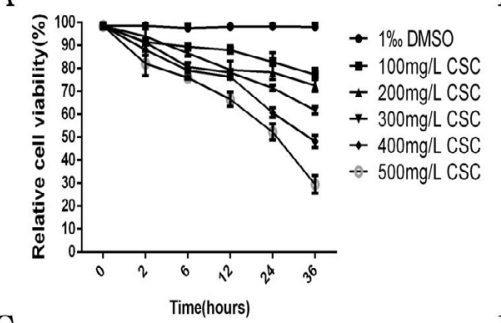

C

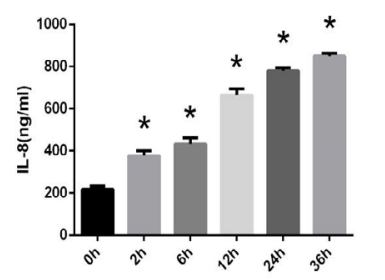

D
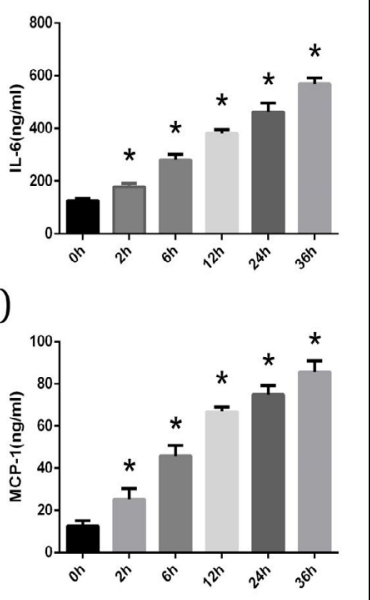
Fig. 2. The effects of CSC on the expression of $\beta$-arrestin2 and autophagy in BEAS-2B cells. (A) Western blot analysis shows changes in the expression of $\beta$-arrestin 2 and the autophagy-associated proteins, P62 and LC3-II, in BEAS-2B cells at different time points after exposure to $300 \mathrm{mg} / \mathrm{L}$ CSC. (B) Quantification of $\beta$-arrestin2 protein by densitometry. (C) Quantification of P62 protein by densitometry. (D) Quantification of LC3-II protein by densitometry. Data represent the mean $\pm \mathrm{SD}$ of three independent experiments. ${ }^{*} \mathrm{P}<0.05$ vs. the control group.

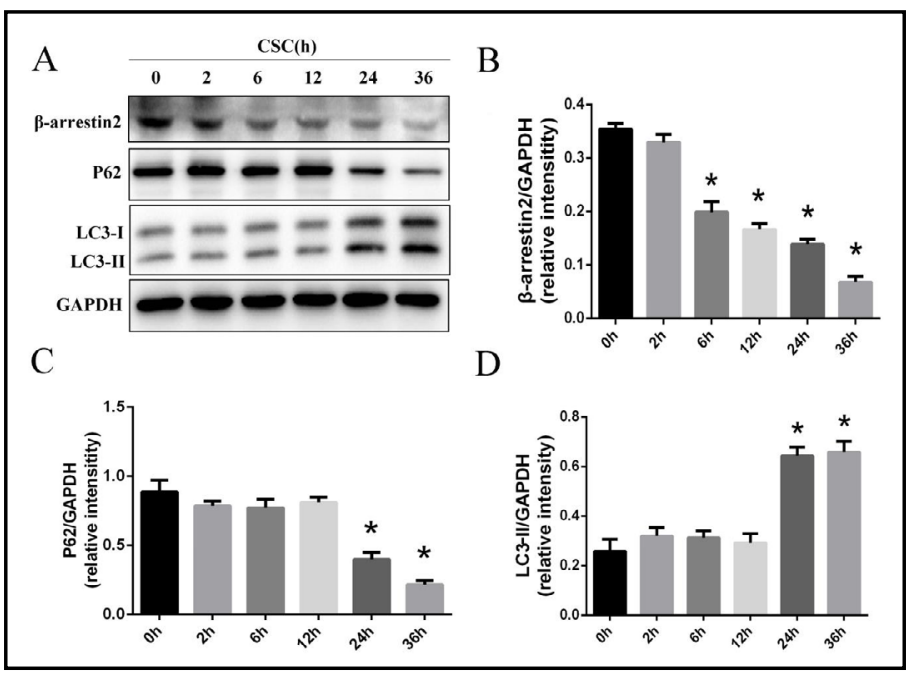

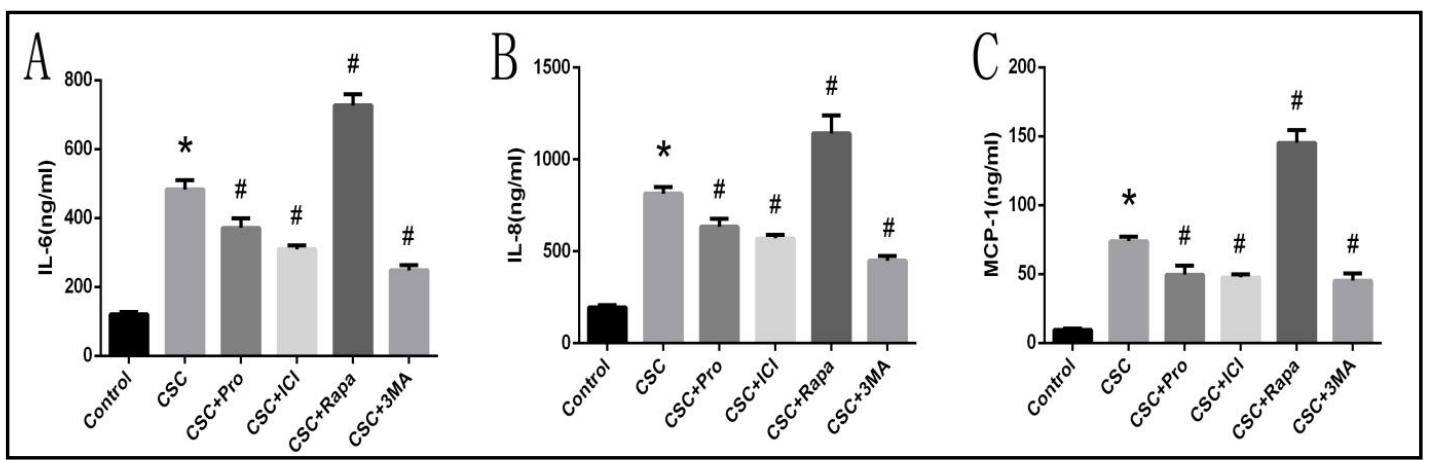

Fig. 3. Differences in inflammatory cytokine secretion induced by exposure to CSC in different groups. (A, B, C) Concentration of the inflammatory cytokines IL-6, IL-8 and MCP-1 in the supernatant of BEAS-2B cells after CSC (300 mg/L) interventions for $24 \mathrm{~h}$ and different drug interventions: propranolol $(10 \mu \mathrm{M})$, ICI118551 $(1 \mu \mathrm{M})$, rapamycin $(50 \mathrm{nM})$, and 3-MA $(200 \mu \mathrm{M}))$ for $1 \mathrm{~h}$ before CSC $(300 \mathrm{mg} / \mathrm{L})$. Data represent the mean \pm SD of three independent experiments. ${ }^{*} \mathrm{P}<0.05$ vs. the control group. $\# \mathrm{P}<0.05$ vs. the CSC group.

$\beta$-arrestin2 inhibited the expression of inflammatory cytokines induced by CSC in BEAS-2B cells

The effects of $\beta$-arrestin 2 on the CSC-induced expression of inflammatory cytokines were investigated by measuring the concentration of IL-6, IL-8, and MCP-1 in the cell supernatant. As shown in Fig. 3, the ELISA results showed that CSC increased the levels of IL-6, IL-8, and MCP-1 and that pretreatment with propranolol $(10 \mu \mathrm{M})$ and ICI118551 $(1 \mu \mathrm{M})$ significantly reduced the levels of these inflammatory cytokines. Pretreatment of BEAS-2B cells was undertaken with the autophagy inducer, rapamycin $(50 \mathrm{nM})$, and the autophagy inhibitor, 3MA $(200 \mu \mathrm{M})$, prior to CSC intervention. Data showed that the inhibition of autophagy reduced the levels of all inflammatory cytokines, IL-6, IL-8, and MCP-1.

\section{$\beta$-arrestin2 inhibited autophagy induced by CSC in BEAS-2B cells}

$\beta$-arrestin 2 has been previously shown to be involved in the regulation of autophagy in diabetic nephropathy [39]. Next,we sought to determine whether $\beta$-arrestin2 regulates CSC-induced autophagy. Fig. 4 shows that CSC significantly reduced the expression level of $\beta$-arrestin2 and significantly increased autophagy levels in BEAS-2B cells, $24 \mathrm{~h}$ after CSC exposure. Pretreatment with the $\beta$-arrestin2-biased ligands, propranolol and ICI118551, significantly increased the expression levels of $\beta$-arrestin2 (Fig. 4B), increased the expression levels of P62 (Fig. 4D) and inhibited the expression levels of LC3-II (Fig. 4E). Rapamycin also activated autophagy, while 3MA inhibited autophagy. 


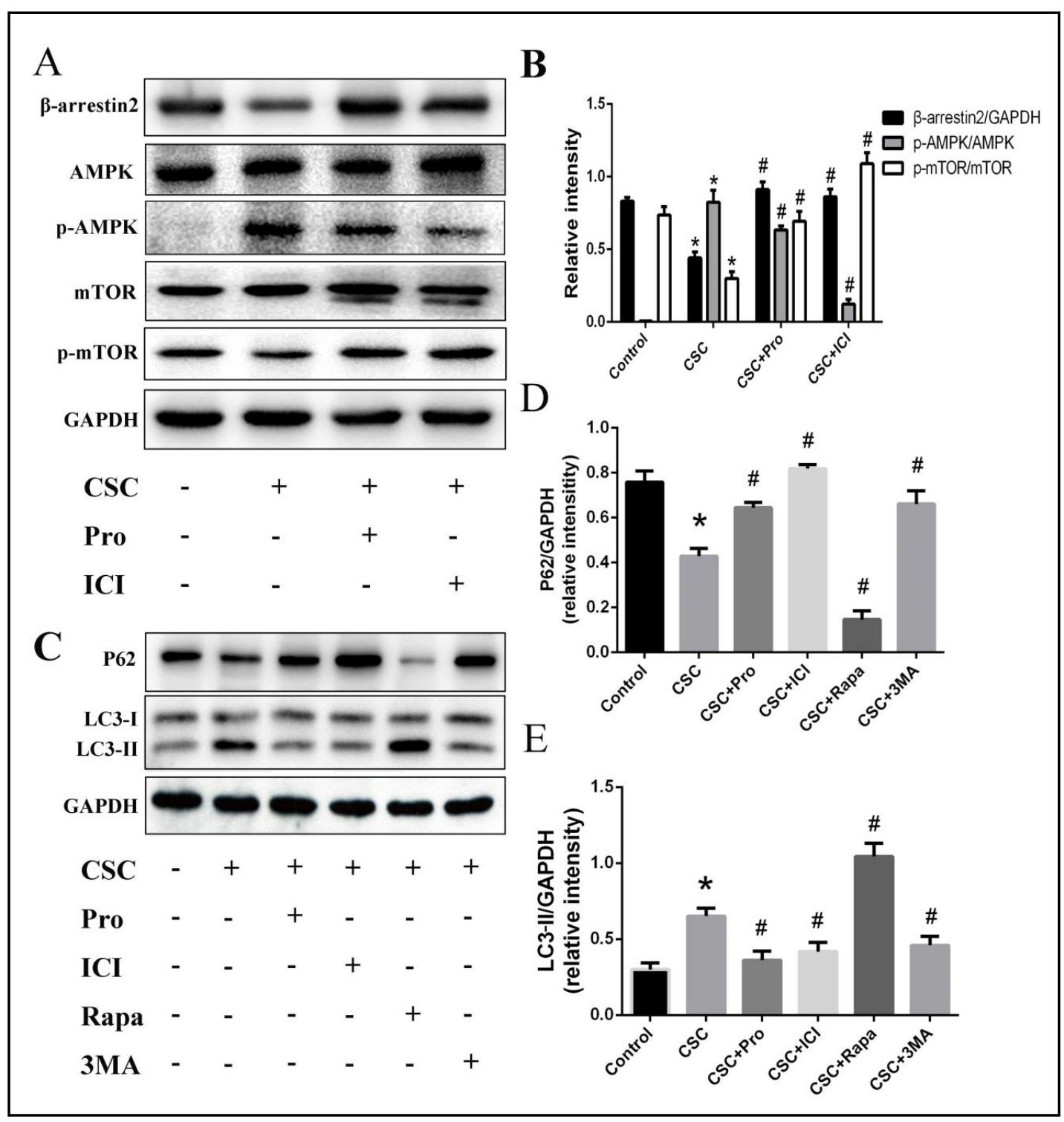

Fig. 4. $\beta$-arrestin 2 inhibits autophagy induced by CSC in BEAS-2B cells. (A) Western blot analysis shows changes in the expression of $\beta$-arrestin2, p-AMPK, AMPK, p-mTOR, and mTOR in BEAS-2B cells treated with propranolol $(10 \mu \mathrm{M})$ and ICI118551 $(1 \mu \mathrm{M})$ for $1 \mathrm{~h}$ before exposure to CSC (300 $\mathrm{mg} / \mathrm{L})$. (B) Quantification of $\beta$-arrestin2, p-AMPK/AMPK and p-mTOR/mTOR by densitometry. (C) Western blot analysis shows changes in the expression of the autophagy-associated proteins, P62 and LC3-II, in BEAS-2B cells treated with propranolol $(10 \mu \mathrm{M})$, ICI118551 $(1 \mu \mathrm{M})$, rapamycin $(50 \mathrm{nM})$ and 3-MA $(200 \mu \mathrm{M})$ for $1 \mathrm{~h}$ before exposure to CSC (300 mg/L). (D) Quantification of P62 protein by densitometry. (E) Quantification of LC3-II protein ratio by densitometry. Data represent the mean $\pm \mathrm{SD}$ of three independent experiments. ${ }^{*} \mathrm{P}<0.05$ vs. the control group. \#P $<0.05$ vs. the CSC group.

To support these findings on the effect of $\beta$-arrestin2 on autophagy, the number of autophagosomes and autolysosomes were evaluated following the transfection of adenoviral mRFP-GFP-LC3 into CSC-induced BEAS-2B cells. Both the number of autophagosomes (yellow dots) and autolysosomes (red dots) after merging, significantly increased with CSC treatment, indicating that CSC enhanced autophagy in BEAS-2B cells. Pretreatment with propranolol or ICI118551 significantly reduced the number of both autophagosomes and autolysosomes (Fig. 5A, 5B). These findings showed that $\beta$-arrestin2 reduced autophagy induced by CSC in BEAS-2B cells in vitro.

\section{KARGER}




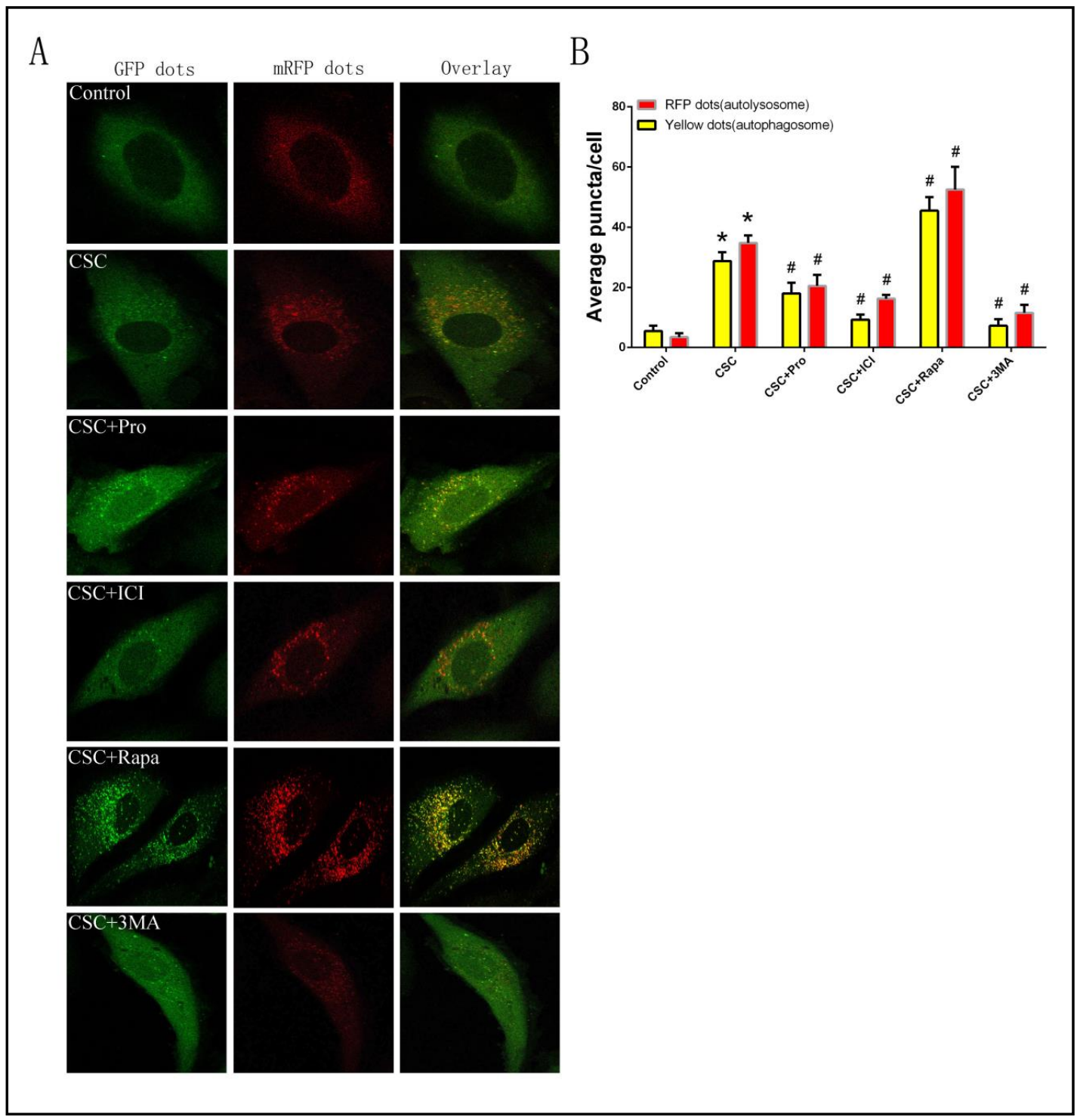

Fig. 5. Changes of autophagy flow in response to different drug interventions: propranolol $(10 \mu \mathrm{M})$, ICI118551 $(1 \mu \mathrm{M})$, rapamycin $(50 \mathrm{nM})$, and 3-MA $(200 \mu \mathrm{M})$ for $1 \mathrm{~h}$ before exposure to CSC $(300 \mathrm{mg} / \mathrm{L})$. (A) Confocal fluorescence microscopy of BEAS-2B cells show the yellow dots, representing autophagosomes, and the red dots representing autolysosomes. Magnification x 600. (B) The intensity of autophagic change determined by counting the different colored fluorescent dots on confocal microscopy. Data represent the mean \pm SD of four independent experiments. ${ }^{*} \mathrm{P}<0.05$ vs. the control group. \#P $<0.05$ vs. the CSC group.

Knockdown of $\beta$-arrestin2 enhances autophagy and inflammation induced by CSC

To further study the effects of $\beta$-arrestin2 on autophagy and inflammation induced by CSC, BEAS-2B cells were transfected with lentiviral $\beta$-arrestin2 shRNA. Western blot (Fig. 6A, 6B) and real-time RT-PCR (Fig. 6C) showed that the expression of $\beta$-arrestin2 was successfully knocked down. Downregulation of $\beta$-arrestin2 with shRNA increased the expression of inflammatory cytokines (Fig. 6D, 6E, 6F) and the level of autophagy (Fig. 7). The expression of P62 was supported by immunofluorescence assays (Fig. 7C), which showed that the knockdown of $\beta$-arrestin2 also reduced the levels of P62 in CSC-induced BEAS-2B cells. These results provide more evidence that $\beta$-arrestin2 inhibited autophagy and inflammation induced by CSC in BEAS-2B cells.

\section{KARGER}




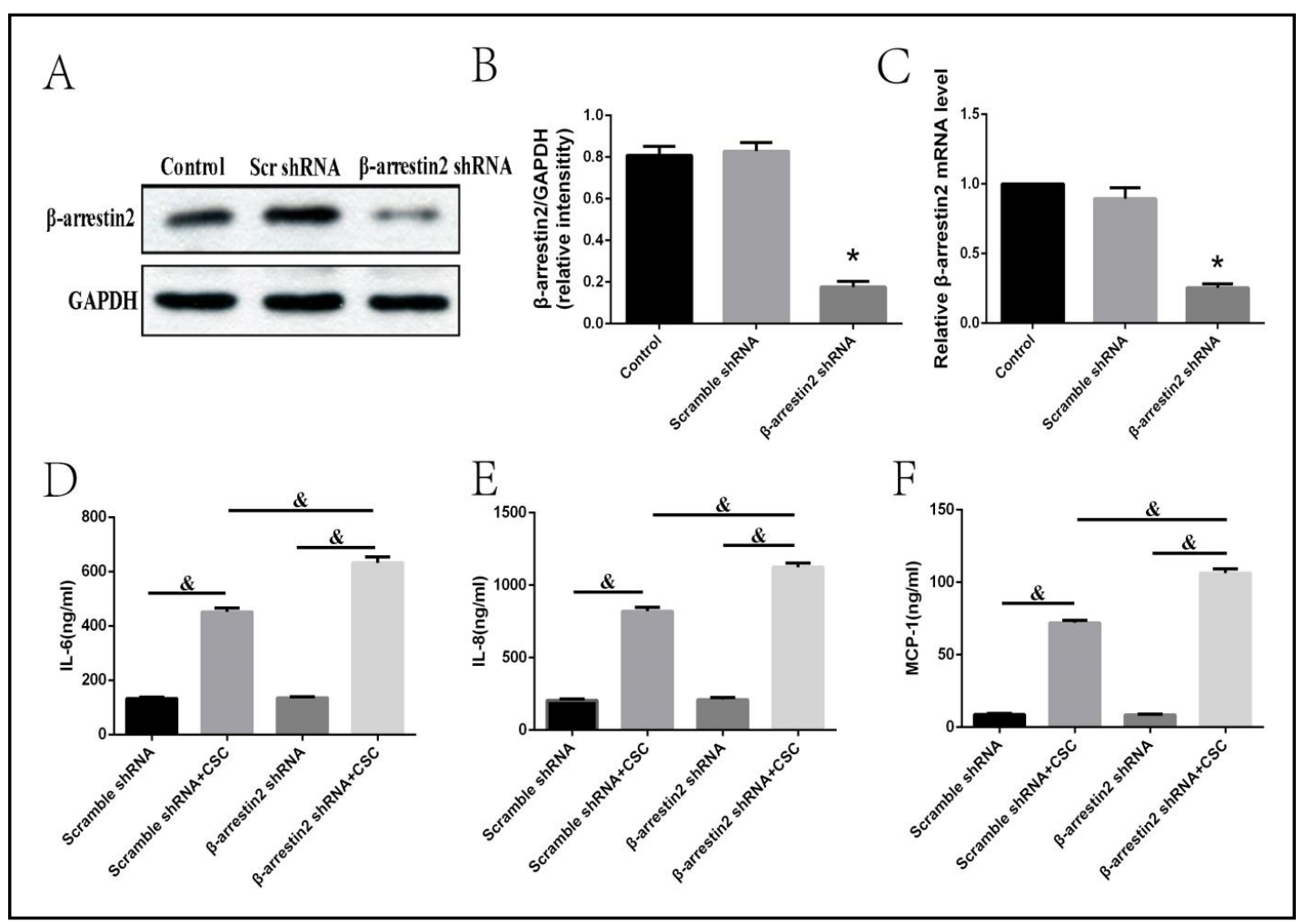

Fig. 6. Knockdown of $\beta$-arrestin2 increased the expression of inflammatory cytokines induced by CSC. (A) Western blot analysis shows changes of $\beta$-arrestin2 in Beas-2B cells transfected with lentiviral $\beta$-arrestin2 shRNA with a multiplicity of infection (MOI) value of 5. (B) Quantification of $\beta$-arrestin2 protein by densitometry. (C) The effect of $\beta$-arrestin2 shRNA knockdown was identified by real-time reverse transcription polymerase chain reaction (RT-PCR). (D, E, F) Concentration of the inflammatory cytokines, IL-6, IL-8, and MCP-1, in the supernatant of Beas-2B cells transfected with lentiviral $\beta$-arrestin2 shRNA and scramble shRNA with or without CSC (300 mg/L) intervention for $24 \mathrm{~h}$. Data represent the mean \pm SD of three independent experiments. ${ }^{*} \mathrm{P}<0.05$ vs. scramble shRNA group. $\& \mathrm{P}<0.05$.

$\beta$-arrestin2 blocks CSC-induced autophagy through the AMPK/mTOR signaling pathway

Previous research has shown that the AMPK/mTOR signaling pathway regulates autophagy and that this pathway is also involved in cigarette smoke-induced autophagy [42]. To determine whether $\beta$-arrestin 2 suppresses CSC-induced autophagy through the AMPK/mTOR pathway, we evaluated the expression of p-AMPK/AMPK and p-mTOR/ mTOR by western blot, which is consistent with the findings from a previous study [43]. Western blot data showed that CSC exposure increased levels of p-AMPK, but reduced levels of p-mTOR, and that pretreatment with propranolol and ICI118551 significantly inhibited the phosphorylation of AMPK and increased the phosphorylation of mTOR (Fig. 4A, 4B). The expression of the AMPK/mTOR signaling pathway components were detected after knockdown of $\beta$-arrestin2. As shown in Fig. 7A and 7B, after knockdown of $\beta$-arrestin2, phosphorylation of AMPK was increased and phosphorylation of mTOR was decreased in the CSC exposure group, which suggested that $\beta$-arrestin2 blocked CSC-induced autophagy via the AMPK/mTOR signaling pathway. 


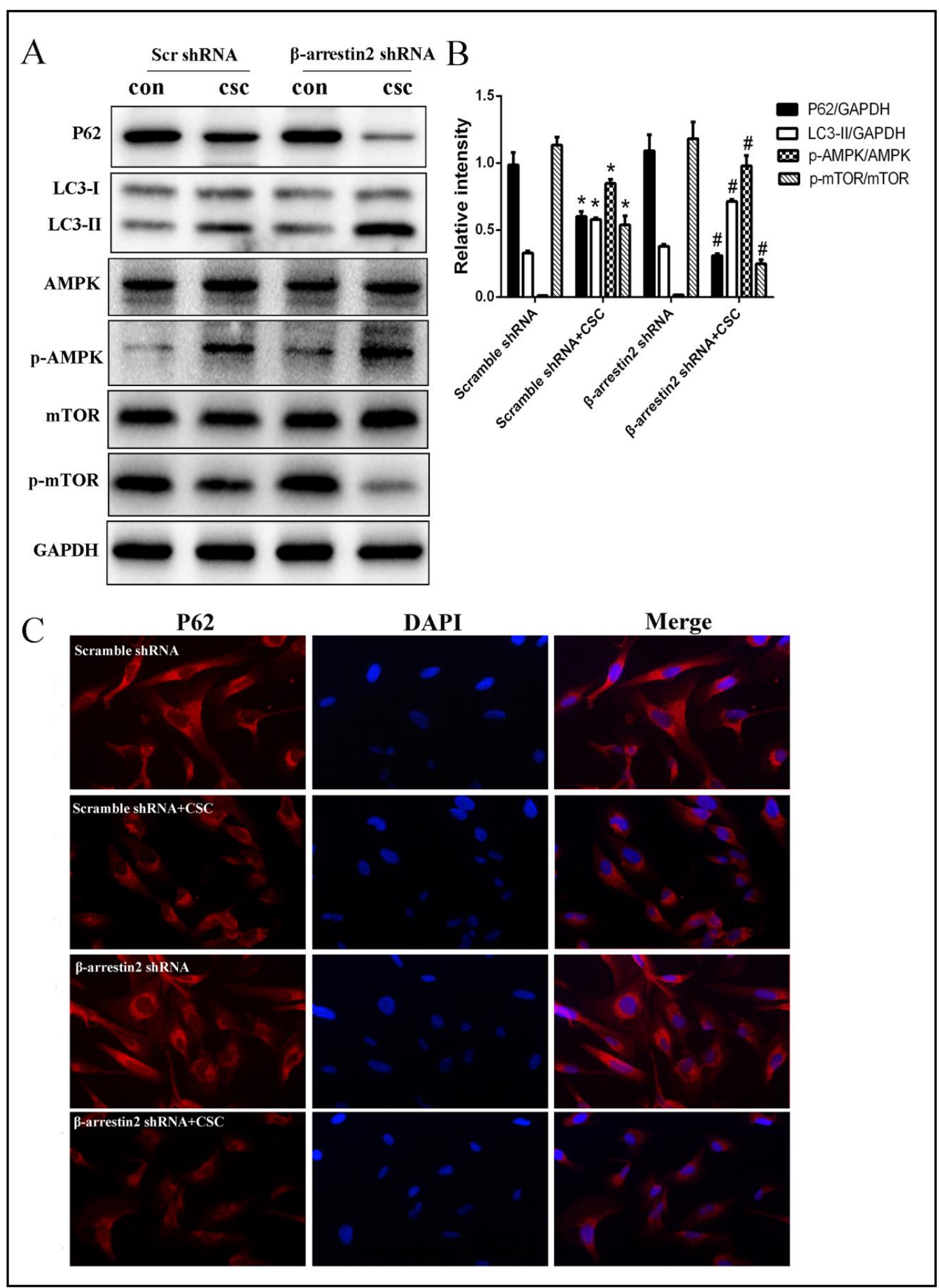

Fig. 7. Knockdown of $\beta$-arrestin 2 enhanced autophagy induced by exposure to CSC. (A) Western blot analysis shows changes in the expression of the proteins P62, LC3-II, p-AMPK, AMPK, p-mTOR and mTOR, in BEAS$2 \mathrm{~B}$ cells transfected with lentiviral $\beta$-arrestin2 shRNA and scramble shRNA with or without exposure to CSC (300 mg/L) for 24 h. (B) Quantification of P62, LC3-II, p-AMPK/AMPK and p-mTOR/mTOR by densitometry. C) Immunofluorescence analysis shows changes in the expression of the autophagy-associated protein P62. Data represent the mean \pm SD of three independent experiments. ${ }^{*} \mathrm{P}<0.05$ vs. scramble shRNA group. \#P $<0.05$ vs. scramble shRNA + CSC group. 


\section{Cellular Physiology Cell Physiol Biochem 2018;50:1270-1285

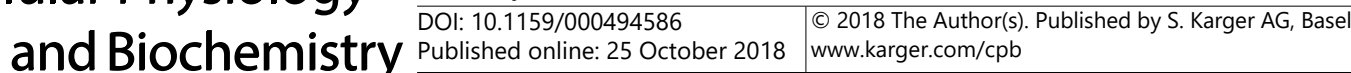

Wu et al.: The Role of $\beta$-Arrestin2 in Inflammation of Beas-2B Cells Induced by CSC

\section{Discussion}

To the best of our knowledge, this study is the first to investigate the relationship between CSC, $\beta$-arrestin2, autophagy, and the expression of inflammatory cytokines, IL-6, IL-8, and MCP-1 in bronchial epithelial cells in vitro. The findings of this study showed that in the human bronchial epithelial cell line, BEAS-2B, $\beta$-arrestin2 reduced the expression of CSC-induced inflammatory cytokines by inhibiting autophagy, possibly via the AMPK/ mTOR signaling pathway. Although this was a preliminary study using a cultured bronchial epithelial cell line, the findings of the study may have implications for further studies on the mechanisms of inflammation in the lung, including in chronic obstructive pulmonary disease (COPD).

$\beta$-arrestins are closely related to G-protein-coupled receptors and have mainly been studied in the cardiovascular system. However, the roles of $\beta$-arrestins in the respiratory system are not yet fully understood. Recently, $\beta$-arrestins have become new targets for drug discovery and development, with the aim to discover $\beta$-arrestin-biased ligand drugs to provide the protective effects of $\beta$-arrestin on cardiomyocytes and inhibit G-proteinmediated myocardial toxicity. For example, Monasky et al. have shown that the $\beta$-arrestin biased ligand, TRV120023, inhibited angiotensin II-induced cardiac hypertrophy [44]. It has also previously been shown that the $\beta 2$-adrenergic receptor agonist, fenoterol, can downregulate toll-like receptor signaling through the $\beta$-arrestin2/AMPK pathway and exert antiinflammatory effects [45]. Zhou et al. showed that $\beta$-arrestin2 was involved in the secretion of airway mucus in COPD, and that propranolol or ICI118551 can act on the $\beta$-arrestin2/ ERK 1/2, p38, MAPK/MUC5AC pathways by blocking transcription and expression of the MUC5AC gene, to reduce airway mucus hypersecretion induced by cigarette smoke [46]. Lee et al. showed that indacaterol could reduce the expression of MMP-9 by inhibiting NF- $\kappa B$ via the activation of $\beta$-arrestin2 [47]. The findings of these previous studies raise the possibility that $\beta$-arrestin2 might play a role in the pathogenesis of COPD.

Because COPD is associated with smoking, when planning the present study, it was necessary to investigate whether $\beta$-arrestin 2 was involved in inflammation and autophagy in the bronchial epithelial cells in response to the effects of cigarette smoke. Therefore, the human bronchial epithelial cell line, BEAS-2B, was chosen and the effects of CSC on autophagy, the expression of $\beta$-arrestin2, and the expression of IL-6, IL-8, and MCP- 1 were studied. The findings of this study showed that the expression of $\beta$-arrestin 2 decreased when cells were stimulated by CSC but the levels of autophagy and inflammatory cytokines increased. Treatment with the $\beta$-arrestin2 biased ligands, propranolol or ICI118551, led to a reduction in the expression of CSC-induced autophagy levels and inflammatory cytokines.

Autophagy has roles in both normal physiological processes and in pathological processes, and although the role of autophagy in human disease remains poorly understood, a further understanding of autophagy in diseases such as COPD may provide approaches to prevention, diagnosis, or treatment. Previous studies have shown that autophagy represents a 'double-edged sword' that has been associated with both protective and detrimental effects. Autophagy is a process that degrades damaged proteins or organelles, maintaining physiological cell metabolism, but excessive or impaired autophagy can promote an inflammatory response and is associated with apoptosis [25, 48]. A recently published study by Vij et al. showed that cigarette smoke can induce impaired autophagy, thereby aggravating the aging of lungs and exacerbating COPD-emphysema [30].Two previously published studies have also shown that the inhibition of autophagy provided a level of protection against human bronchial epithelial apoptosis induced by cigarette smoke $[49,50]$. Zhou et al. showed that autophagy plays an essential role in cigarette smoke-induced mucus production in airway epithelium, both in vitro and in vivo, and inhibition of autophagy was also shown to markedly reduce cigarette smoke extract-induced bronchial mucus production [51]. Therefore, autophagy appears to have a detrimental role in current models of COPD.

In the present study, the levels of autophagy and the expression of inflammatory cytokines were shown to increase after BEAS-2B cells were stimulated with CSC. Following 


\section{Cellular Physiology Cell Physiol Biochem 2018;50:1270-1285 \begin{tabular}{ll|l} 
DOl: 10.1159/000494586 & $\begin{array}{l}\text { O } 2018 \text { The Author(s). Published by S. Karger AG, Basel } \\
\text { www.karger.com/cpb }\end{array}$
\end{tabular}

the addition of rapamycin, which is an activator of autophagy, both the level of autophagy and the expression of inflammatory cytokines increased; when the autophagy inhibitor, $3 \mathrm{MA}$, was added the level of autophagy and the expression of inflammatory cytokines decreased. These results indicated that cigarette smoke activated autophagy and induced the secretion of inflammatory cytokines in BEAS-2B cells and that the inhibition of autophagy inhibited the CSC-induced inflammatory response. In a previously published study by our group, we showed that in CSC-induced BEAS-2B cells, autophagy promoted secretion of the inflammatory cytokines, IL-6, IL-8, and MCP-1, by reducing p62 aggregation, which reduced translocation of Nrf2 into the nucleus, downregulating the expression of heme oxygenase-1 (HO-1), which can reduce the expression of inflammatory cytokines [29].

To investigate the effect of $\beta$-arrestin 2 on autophagy, in the present study, the $\beta$-arrestin2 agonists, propranolol and ICI118551 were used. Western blot showed that following propranolol and ICI118551 treatment, the expression of $\beta$-arrestin2 increased and the level of autophagy decreased. The findings from the ELISA data also showed that the expression levels of inflammatory cytokines were reduced. To further investigate the interaction between $\beta$-arrestin2 and autophagy, BEAS-2B cells were transfected with $\beta$-arrestin 2 shRNA to knock down the expression of $\beta$-arrestin2. The level of autophagy and inflammatory factors increased after cigarette smoke exposure compared with cells that were treated with scramble shRNA. These results supported that $\beta$-arrestin2 inhibited CSCinduced inflammation in BEAS-2B cells in vitro by inhibiting autophagy.

The present study also included a preliminary investigation of the possible pathway by which $\beta$-arrestin 2 mediates autophagy. As a highly conserved serine/threonine kinase in eukaryotes, adenosine monophosphate-activated protein kinase (AMPK) plays an important role in cell nutrition, energy loss, and oxidative stress [52, 53]. A previous study showed that exposure to cigarette smoke increased the phosphorylation of AMPK in primary culture of cerebral endothelial cells in the C57BL/6 mouse [43]. Exposure to cigarette smoke has been shown to increase AMPK activation in the lungs in a CSC concentration-dependent and timedependent manner [54]. A recent study also showed that the activation of mTOR suppressed airway inflammation and emphysema induced by cigarette smoke via the inhibition of autophagy and cell death [55]. Furlong et al. showed that in the mouse ovary, cigarette smoke exposure activated autophagy by upregulating the AMPK/mTOR pathway [42]. The present study also demonstrated that cigarette smoke induced AMPK activation and activated autophagy through the AMPK/mTOR pathway. Pre-treatment with propranolol or ICI118551 was also shown to inhibit the AMPK/mTOR signaling pathway, and to inhibit autophagy by restoring the levels of $\beta$-arrestin2 in BEAS-2B cells. These changes were reversed with the knockdown of $\beta$-arrestin2, indicating that $\beta$-arrestin2 suppressed autophagy through the AMPK-mTOR signaling pathway.

This study had several limitations and was a preliminary in vitro study of a single bronchial epithelial cell line and did not involve the use of an in vivo animal model or tissue analysis from patients with COPD. However, the findings of this study may provide the basis for future studies on $\beta$-arrestin 2 and the AMPK/mTOR signaling pathway in chronic inflammatory lung disease, including COPD.

\section{Conclusion}

In conclusion,In the human bronchial epithelial cell line, BEAS-2B, $\beta$-arrestin2 reduced the expression of CSC-induced inflammatory cytokines by inhibiting autophagy, most likely via the AMPK/mTOR signaling pathway. The preliminary findings of this in vitro study require support with further studies to determine whether $\beta$-arrestin 2 might provide a potential therapeutic target for patients with COPD. 


\section{Cellular Physiology Cell Physiol Biochem 2018;50:1270-1285 \begin{tabular}{ll|l} 
DOI: 10.1159/000494586 & $\begin{array}{l}\text { O 2018 The Author(s). Published by S. Karger AG, Basel } \\
\text { www.karger.com/cpb }\end{array}$ \\
\hline
\end{tabular}}

Wu et al.: The Role of $\beta$-Arrestin2 in Inflammation of Beas-2B Cells Induced by CSC

\section{Acknowledgements}

The study was supported by the National Natural Science Foundation of China (Ref: 81700038), the Capital's Funds for Health Improvement and Research (Ref: 2018-2-2024), and the Beijing Municipal Science and Technology Commission (Ref: Z151100003915135).

\section{Disclosure Statement}

The authors have no conflicts of interest to disclose.

\section{References}

1 Su Y, Long C, Yu Q, Zhang J, Wu D, Duan Z: Global scientific collaboration in COPD research. Int J Chron Obstruct Pulmon Dis 2017;12:215-225.

-2 Ding B, Small M, Bergström G, Holmgren U: COPD symptom burden: impact on health care resource utilization, and work and activity impairment. Int J Chron Obstruct Pulmon Dis 2017;12:677-689.

3 Yu G, Zeng X, Wang H, Hou Q, Tan C, Xu Q, Wang H: 14, 15-epoxyeicosatrienoic acid suppresses cigarette smoke extract-induced apoptosis in lung epithelial cells by inhibiting endoplasmic reticulum stress.Cell Physiol Biochem 2015;36:474-486.

-4 Burney P, Kato B, Janson C, Mannino D, Studnicka M, Tan W, Bateman E, Koçabas A, Vollmer WM, Gislason T, Marks G, Koul PA, Gnatiuc L, Gnatiuc L, Buist S: Chronic obstructive pulmonary disease mortality and prevalence: the associations with smoking and poverty: a BOLD analysis--authors' reply. Thorax 2014;69:869-870.

-5 Yuan H, Shyy JY, Martins-Green M: Second-hand smoke stimulates lipid accumulation in the liver by modulating AMPK and SREBP-1. J Hepatol 2009;51:535-547.

$\checkmark 6$ Colarusso C, Terlizzi M, Molino A, Pinto A, Sorrentino R: Role of the inflammasome in chronic obstructive pulmonary disease (COPD). Oncotarget 2017;8:81813-81824.

7 Barnes PJ: Inflammatory mechanisms in patients with chronic obstructive pulmonary disease. J Allergy Clin Immunol 2016;138:16-27.

8 Benovic JL, Kühn H, Weyand I, Codina J, Caron MG, Lefkowitz RJ: Functional desensitization of the isolated beta-adrenergic receptor by the beta-adrenergic receptor kinase: potential role of an analog of the retinal protein arrestin (48-kDa protein). Proc Natl Acad Sci U S A 1987;84:8879-8882.

9 Smith JS, Rajagopal S: The $\beta$-Arrestins: Multifunctional Regulators of G Protein-coupled Receptors. J Biol Chem 2016;291:8969-8977.

10 Reiter E, Ahn S, Shukla AK, Lefkowitz RJ: Molecular mechanism of $\beta$-arrestin-biased agonism at seventransmembrane receptors. Annu Rev Pharmacol Toxicol 2012;52:179-197.

11 Lefkowitz RJ, Shenoy SK: Transduction of receptor signals by beta-arrestins. Science 2005;308:512-517.

12 Liu X, Ma L, Li HH, Huang B, Li YX, Tao YZ, Ma L: $\beta$-Arrestin-biased signaling mediates memory reconsolidation. Proc Natl Acad Sci U S A 2015;112:4483-4488.

$>13$ Goodman OB, Krupnick JG, Santini F, Gurevich VV, Penn RB, Gagnon AW, Keen JH, Benovic JL: Beta-arrestin acts as a clathrin adaptor in endocytosis of the beta2-adrenergic receptor. Nature 1996;383:447-450.

14 Whalen EJ, Rajagopal S, Lefkowitz RJ: Therapeutic potential of $\beta$-arrestin- and G protein-biased agonists. Trends Mol Med 2011;17:126-139.

15 Lefkowitz RJ, Rajagopal K, Whalen EJ: New roles for beta-arrestins in cell signaling: not just for seventransmembrane receptors. Mol Cell 2006;24:643-652.

16 Carr R, Schilling J, Song J, Carter RL, Du Y, Yoo SM, Traynham CJ, Koch WJ, Cheung JY, Tilley DG, Benovic JL: $\beta$ arrestin-biased signaling through the $\beta 2$-adrenergic receptor promotes cardiomyocyte contraction. Proc Natl Acad Sci U S A 2016;113:E4107-4116.

-17 Yoshimori T: Autophagy: a regulated bulk degradation process inside cells. Biochem Biophys Res Commun 2004;313:453-458.

18 Ureshino RP, Rocha KK, Lopes GS, Bincoletto C, Smaili SS: Calcium signaling alterations, oxidative stress, and autophagy in aging. Antioxid Redox Signal 2014;21:123-137. 


\section{Cellular Physiology Cell Physiol Biochem 2018;50:1270-1285

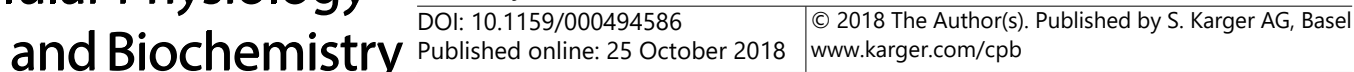

Wu et al.: The Role of $\beta$-Arrestin2 in Inflammation of Beas-2B Cells Induced by CSC

19 Ryter SW, Koo JK, Choi AM: Molecular regulation of autophagy and its implications for metabolic diseases. Curr Opin Clin Nutr Metab Care 2014;17:329-337.

-20 Hasima N, Ozpolat B: Regulation of autophagy by polyphenolic compounds as a potential therapeutic strategy for cancer. Cell Death Dis 2014;5:e1509.

-21 Chen YF, Liu H, Luo XJ, Zhao Z, Zou ZY, Li J, Lin XJ, Liang Y: The roles of reactive oxygen species (ROS) and autophagy in the survival and death of leukemia cells. Crit Rev Oncol Hematol 2017;112:21-30.

-22 Li L, Tan J, Miao Y, Lei P, Zhang Q: ROS and Autophagy: Interactions and Molecular Regulatory Mechanisms. Cell Mol Neurobiol 2015;35:615-621.

-23 Liu H, Cao MM, Wang Y, Li LC, Zhu LB, Xie GY, Li YB: Endoplasmic reticulum stress is involved in the connection between inflammation and autophagy in type 2 diabetes.Gen Comp Endocrinol 2015;210:124129.

24 Hosomi S, Kaser A, Blumberg RS: Role of endoplasmic reticulum stress and autophagy as interlinking pathways in the pathogenesis of inflammatory bowel disease. Curr Opin Gastroenterol 2015;31:81-88.

25 Racanelli AC, Kikkers SA, AMK C, Cloonan SM: Autophagy and inflammation in chronic respiratory disease. Autophagy 2018;14: 221-232.

26 Bodas M, Min T, Vij N: Lactosylceramide-accumulation in lipid-rafts mediate aberrant-autophagy, inflammation and apoptosis in cigarette smoke-induced emphysema. Apoptosis 2015;20:725-739.

-27 Li Y, Yu G, Yuan S, Tan C, Lian P, Fu L, Hou Q Xu B, Wang H: Cigarette Smoke-Induced Pulmonary Inflammation and Autophagy Are Attenuated in Ephx2-Deficient Mice. Inflammation 2017;40:497-510.

28 Li D, Hu J, Wang T, Zhang X, Liu L, Wang H, Wu Y, Xu D, Wen F: Silymarin attenuates cigarette smoke extractinduced inflammation via simultaneous inhibition of autophagy and ERK/p38 MAPK pathway in human bronchial epithelial cells. Sci Rep 2016;6:37751.

29 Li Y, Yu G, Yuan S, Tan C, Xie J, Ding Y, Lian P, Fu L, Hou Q Xu B, Wang H: 14, 15-epoxyeicosatrienoic acid suppresses cigarette smoke condensate-induced inflammation in lung epithelial cells by inhibiting autophagy. Am J Physiol Lung Cell Mol Physiol 2016;311:L970-L980.

-30 Vij N, Chandramani P, Westphal CV, Hole R, Bodas M: Cigarette smoke-induced autophagy-impairment accelerates lung aging, COPD-emphysema exacerbations and pathogenesis. Am J Physiol Cell Physiol 2018;314:C73-C87.

31 Klionsky DJ, Abdelmohsen K, Abe A, Abedin MJ, Abeliovich H, Acevedo Arozena A, Adachi H, Adams CM, Adams PD, Adeli K, Adhihetty PJ, Adler SG, Agam G, Agarwal R, Aghi MK, Agnello M, Agostinis P, Aguilar PV, Aguirre-Ghiso J, Airoldi EM et al.: Guidelines for the use and interpretation of assays for monitoring autophagy (3rd edition). Autophagy. 2016;12:1-222.

-32 Qian L, Wu HM, Chen SH, Zhang D, Ali SF, Peterson L, Wilson B, Lu RB, Hong JS, Flood PM: $\beta 2$-adrenergic receptor activation prevents rodent dopaminergic neurotoxicity by inhibiting microglia via a novel signaling pathway. J Immunol 2011;186:4443-4454.

-33 Urs NM, Bido S, Peterson SM, Daigle TL, Bass CE, Gainetdinov RR, Bezard E, Caron MG: Targeting $\beta$-arrestin2 in the treatment of L-DOPA-induced dyskinesia in Parkinson's disease. Proc Natl Acad Sci U S A 2015;112:E2517-2526.

34 Ryba DM, Li J, Cowan CL, Russell B, Wolska BM, Solaro RJ: Long-Term Biased $\beta$-Arrestin Signaling Improves Cardiac Structure and Function in Dilated Cardiomyopathy. Circulation 2017;135:1056-1070.

-35 Chen T, Zheng F, Tao J, Tan S, Zeng L, Peng X, Wu B: Insulin-Like Growth Factor-1 Contributes to Mucosal Repair by $\beta$-Arrestin2-Mediated Extracellular Signal-Related Kinase Signaling in Experimental Colitis. Am J Pathol 2015;185:2441-2253.

-36 Sun WY, Hu SS, Wu JJ, Huang Q, Ma Y, Wang QT, Chen JY, Wei W: Down-regulation of $\beta$-arrestin2 promotes tumour invasion and indicates poor prognosis of hepatocellular carcinoma. Sci Rep 2016;6:35609.

-37 Gaffal E, Jakobs M, Glodde N, Schröder R, Kostenis E, Tüting T: $\beta$-arrestin 2 inhibits proinflammatory chemokine production and attenuates contact allergic inflammation in the skin. J Invest Dermatol 2014;134:2131-2137.

-38 Zhang Y, Liu C, Wei B, Pei G: Loss of $\beta$-arrestin 2 exacerbates experimental autoimmune encephalomyelitis with reduced number of Foxp3+CD4+ regulatory T cells. Immunology 2013;140:430-440.

39 Liu J, Li QX, Wang XJ, Zhang C, Duan YQ Wang ZY, Zhang Y, Yu X, Li NJ, Sun JP, Yi F: $\beta$-Arrestins promote podocyte injury by inhibition of autophagy in diabetic nephropathy. Cell Death Dis 2016;7:e2183. 


\section{Cellular Physiology Cell Physiol Biochem 2018;50:1270-1285

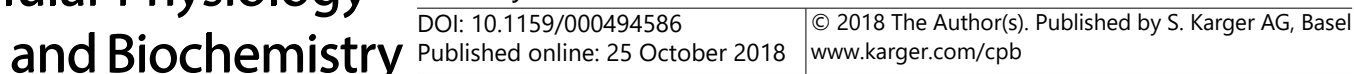

Wu et al.: The Role of $\beta$-Arrestin2 in Inflammation of Beas-2B Cells Induced by CSC

40 Jiang MP, Xu C, Guo YW, Luo QJ, Li L, Liu HL, Jiang J, Chen HX, Wei XQ: $\beta$-arrestin 2 attenuates lipopolysaccharide-induced liver injury via inhibition of TLR4/NF- $\mathrm{KB}$ signaling pathway-mediated inflammation in mice. World J Gastroenterol 2018;24:216-225.

41 Fan H, Bitto A, Zingarelli B, Luttrell LM, Borg K, Halushka PV, Cook JA: Beta-arrestin 2 negatively regulates sepsis-induced inflammation. Immunology 2010;130:344-351.

\$2 Furlong HC, Stämpfli MR, Gannon AM, Foster WG: Cigarette smoke exposure triggers the autophagic cascade via activation of the AMPK pathway in mice. Biol Reprod 2015;93:93.

43 Prasad S, Sajja RK, Kaisar MA, Park JH, Villalba H, Liles T, Abbruscato T, Cucullo L: Role of Nrf2 and protective effects of Metformin against tobacco smoke-induced cerebrovascular toxicity. Redox Biol. 2017;12:58-69.

44 Monasky MM, Taglieri DM, Henze M, Warren CM, Utter MS, Soergel DG, Violin JD, Solaro RJ: The $\beta$-arrestinbiased ligand TRV120023 inhibits angiotensin II-induced cardiac hypertrophy while preserving enhanced myofilament response to calcium. Am J Physiol Heart Circ Physiol 2013;305:H856-866.

45 Wang W, Chen J, Li XG, Xu J: Anti-inflammatory activities of fenoterol through $\beta$-arrestin2 and inhibition of AMPK and NF- $\kappa B$ activation in AICAR-induced THP-1 cells. Biomed Pharmacother 2016;84:185-190.

46 Zhou Y, Zhang Y, Guo Y, Zhang Y, Xu M, He B: $\beta 2$-Adrenoceptor involved in smoking-induced airway mucus hypersecretion through $\beta$-arrestin-dependent signaling. PLoS One 2014;9:e97788.

47 Lee SU, Ahn KS, Sung MH, Park JW, Ryu HW, Lee HJ, Hong ST, Oh SR: Indacaterol inhibits tumor cell invasiveness and MMP-9 expression by suppressing IKK/NF-кB activation. Mol Cells 2014.;37:585-591.

48 Ryter SW, Chen ZH, Kim HP, Choi AM: Autophagy in chronic obstructive pulmonary disease: homeostatic or pathogenic mechanism. Autophagy 2009;5:235-237.

49 Chen ZH, Kim HP, Sciurba FC, Lee SJ, Feghali-Bostwick C, Stolz DB, Dhir R, Landreneau RJ, Schuchert MJ, Yousem SA, Nakahira K, Pilewski JM, Lee JS, Zhang Y, Ryter SW, Choi AM: Egr-1 regulates autophagy in cigarette smoke-induced chronic obstructive pulmonary disease. PLoS One 2008;3:e3316.

$\rightarrow 50$ Kim HP, Wang X, Chen ZH, Lee SJ, Huang MH, Wang Y, Ryter SW, Choi AM: Autophagic proteins regulate cigarette smoke-induced apoptosis: protective role of heme oxygenase-1 Autophagy 2008;4:887-895.

-51 Zhou JS, Zhao Y, Zhou HB, Wang Y, Wu YF, Li ZY, Xuan NX, Zhang C, Hua W, Ying SM, Li W, Shen HH, Chen ZH: Autophagy plays an essential role in cigarette smoke-induced expression of MUC5AC in airway epithelium. Am J Physiol Lung Cell Mol Physiol 2016;310:L1042-1052.

52 Dunlop EA, Tee AR: The kinase triad, AMPK, mTORC1 and ULK1, maintains energy and nutrient homoeostasis. Biochem Soc Trans 2013;41:939-943.

53 Possik E, Jalali Z, Nouët Y, Yan M, Gingras MC, Schmeisser K, Panaite L, Dupuy F, Kharitidi D, Chotard L, Jones RG, Hall DH, Pause A: Folliculin regulates AMPK-dependent autophagy and metabolic stress survival. PLoS Genet 2014;10:e1004273.

54 Lee JS, Park SJ, Cho YS, Huh JW, Oh YM, Lee SD: Role of AMP-Activated Protein Kinase (AMPK) in SmokingInduced Lung Inflammation and Emphysema. Tuberc Respir Dis (Seoul) 2015;78:8-17.

55 Wang Y, Liu J, Zhou JS, Huang HQ, Li ZY, Xu XC, Lai TW, Hu Y, Zhou HB, Chen HP, Ying SM, Li W, Shen HH, Chen ZH: MTOR Suppresses Cigarette Smoke-Induced Epithelial Cell Death and Airway Inflammation in Chronic Obstructive Pulmonary Disease. J Immunol 2018;200:2571-2580. 